て来た $\mathrm{Al}$ 合金と最近開発ざれた Carbonfiber の X線透 過性につき, Phantom を付加し比較すると後者の方加 1. 6〜2.1 倍程度すぐれている.

又 Carbonfiber 圧縮板に組み合わせる堌感紙しして， Plasticbase AS-250 及び AS-330 につき検討した結果， 両者共汇従来の Al base AS- 250 及び AS-330を用いた 組合せより 1.6〜2 倍の感度が得られ，MTFに於々ても 劣るものではなく，このととは臨床撮影に於しても認め られた。

特汇被曝線量の多くなりがちな連続撮影には，Carbon Plate+Plastic base AS-330 の組合せは有用なむのであ ると判断された。

\section{0. 血管拡大撮影におけるコントラスト評価}

山榇大学医学部附属病院 ○児玉潤一郎 · 加賀勇治

江口 陽一・枘繁夫

[目的〕

血管拡大撮影に利いて，さらに良いコントラストを得 るために，拡大率，grid 使用の是非，air-gap の距離に ついて検傠した

[方法]

アクリルにより内径 1 〜 $\mathrm{mm}$ の管を有するファント ムを作成し，その内腔を造影剤で満し，血管模擬ファン トムとした．そしてそれを幾何学的条件を変えて撮影を 行い拡大率とコントラストの関係, gridの有無によるコ ントラストの変化, air-gap とロントラストの関係を求 めた。

〔結果〕

掋大率が 2.5 倍までは，搪大率の上㫧にともないコン トラストは上升するが，3倍以上では変化しない，grid を使用した場合，拡大率 2 倍以下で大きいコントラスト 加上昇するが，2 倍以上では，grid を使用しない時とほ とんど変らない. air-gap が $60 \mathrm{~cm}$ 以下でコシトラスト の低下が著しいが， $60 \mathrm{~cm}$ 以上ではほとんど变らない．

11. アンギォスコープのシネ及びラピッドシーケンスの 解像力について

秋田大学医学部附属病院放射線部 ○畑山 紫・渡㲽靖夫・鎌田良二 清水秀美・二浦初男

循環器X線診断装置が急速譜及してきた。当院す本

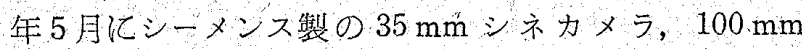
カメラ,プックをそなえた，多方向撮影の出来る偱環 $\mathrm{X}$

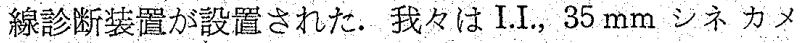
ラ, $100 \mathrm{~mm}$ カ ×ラの解像力等について検討したので報
告する.

I.I. の解像力は非常に良くなり，シネカメラ，100 mm カメラとも冠動脈造影のような細々血管の描出も容易に なってきた. Normal の $25 \mathrm{~cm} \phi$ より, Zoom $017 \mathrm{~cm} \phi$ の方がシネカメラ， $100 \mathrm{~mm}$ カメラと西有利であった， が $100 \mathrm{~mm}$ カメラの方はう゚ログラムの制限を受ける. 現 在撮影条件の問題，被写体の後方散乱による画質の低下， 自現機管理，又未調整部分等の検討を続けていきたいと 考えている.

\section{2. 脳血管拡大連続撮影に於ける幾何学的条件の検討} 秋田脳研

○小野寺洋・佐々木信夫・菅 幹雄 峰谷武憲・厓司 安明. 羽上栄一 相沢康夫

[目的]

微小焦点管球 OPTI 110/12/50 HSG の諸特性と, 正, 側脳血管 2 倍搪大連続撮影のルチン化のために若干の検 討の報告.

[方法]

(1) Focus 測定: Siemens star 及ひ test chart R-4+ Kodak TL+拡大率 3.2 倍, (2) 本X線管球の target 角 度 $10^{\circ}$ 亿対するX線強度の角度分布の影響乞，適正濃度 のための, anode, cathode の位置と FFD の検討. [結果]

(1) 本徵小焦点管球の焦点サイズは， $0.1 \times 0.1 \mathrm{~mm}$ て 管軸に平行方向に設置特より者干大さなって来たが他 $(0.2 \times 0.2 \mathrm{~mm}, 0.6 \times 0.6 \mathrm{~mm})$ 飞変化は認好られなる. (2) 管電圧，管電流は指示值比ほ正確である。 (3) X 線強度の角度分布の影響计大で，乙れをさけるため， (3)-(1)被写体頭頂側K anode 配置する. (3)-(2)頭部 全体を大角フィルムサイズ内にし，しかる拡大率を大き く，更に頭部全体の濃度変化を龍断上，支障を来たさな いために, (3)一(1)の条件と FFD $100 \mathrm{~cm}$ 以上 (可能なら $120 \mathrm{~cm}$ ) 必要.

\section{3. あらゆる照射法に適応可能な線量分布作成プログラ ムの理論}

東北大学医学部附属病院放射線部

○高野正彦

線量分布を演算し描出するには，深部率ならびに軸上 乙軸外の線量の比を求めなけ机ばならないが，さらに入 射面已密度の補正も必要である，X線およびて線们つい ては，すで汇数多くの近似式が報告されている. 今国開 発した演算プログラムでは，深部率てついては指数関数 による近似式を用い，軸上と軸外の線䑁の比は累積分布 